\title{
Nexus between green HRM and green management towards fostering green values
}

\author{
Mahmoud Radwan Hussein AlZgool ${ }^{a^{*}}$
}

${ }^{a}$ College of Administrative and Financial Sciences, Gulf University, Sanad, Kingdom of Bahrain

\begin{tabular}{l}
\hline C H R O N I C L E \\
\hline Article history: \\
Received: June 3, 2019 \\
Received in revised format: June \\
272019 \\
Accepted: June 29, 2019 \\
Available online: \\
June 29, 2019 \\
\hline Keywords: \\
Green HRM \\
Green management \\
Green values \\
Moderation \\
Bahrain
\end{tabular}

\section{A B S T R A C T}

The present study attempted to understand the nexus between Green HRM, Green Management towards explaining individual Green values. The study also attempted to test the moderation of green management on the relationship between Green HRM and individual Green values. A large private distribution business in Bahrain was chosen for the present study based on the recent initiatives towards green practices across the major work prospects. Results of the structural equation modelling from the non-managerial employees of the company indicated significant positive relationship between green HRM and individual green values. Accordingly, the present study also reported significant relationship between Green Management and enhancement of individual green values. Importantly, the study also reported significant moderation of green management on the relationship between green HRM and individual green values. The study forwards implication for practitioners followed by the limitations and scope for future studies.

\section{Introduction}

Green practices, Green HRM, Green management and Green Values; all these have become emerging topics of interest for organizational scientists as well as practitioners. Companies are working with increased sense of responsibility and diligence towards the society and their stake holders (Renwick et al., 2013). More importantly, this has also led towards the development and establishment of societal association at the international level to emphasize organizations on green prospects through highlighting the increased depletion of natural resources and the need for business to play their part. Therein, past studies and scholarly reports have suggested that there are several factors that go hand in hand when it comes to green prospects at work (Jackson \& Seo, 2010). More specifically, studies shave suggested that for organizations aspiring to have green practices in place to be effectively implemented and successful, there is a need to enhance individual green values of the employees (Kumari, 2012). Therefore, to understand this, the present study attempts to empirically test and explore how businesses can enhance their green values through green HRM and green management practices.

\footnotetext{
* Corresponding author.

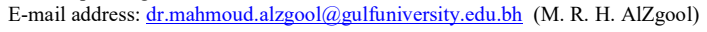




\subsection{Defining Green}

It is very interesting and important to understand what refers to green before explaining green HRM. The term green has been given several meanings. One of the prominent explanations given to this term is environmental friendly, healthy and naïve. In principle, the usage of term green expresses an idea of something being healthy, human and environment friendly. The term has been inspired in the business and corporate dictionaries whereby, organizational enthusiasts have been found using it to refer to practices that could be said as close to nature or the ones that make the least harm to the nature elements. (Oxford, 2000). The term green in the corporate world, gives a sense of something that could being nature friendly and could help to preserve the healthy prospects of it. Alongside this, it also refers to initiation and/or set of activities that could help prevent environmental pollution.

\subsection{Need for Green}

Environment requires its users to have a facilitating and caring attitude so that the resources and nature could be preserved, utilized and maintained for long. This applies to organizations equally whereby, they, with growing environmental concerns are now required to act in a way that facilitates prospects which does not make a detrimental impact on the environment (Haden et al., 2009). Moreover, with the rapid utilization of natural resources, the organizations are now required to act with greener approach, suggesting behaving in a way that could help save natural resources and avoid depletion of such resources (Alshuwaikhat \& Abubakar, 2008). This also requires them to work with an ideology that encourages no destruction of natural resources.

The growing and ever increased utilization of natural resources is gradually leading us to a chaotic situation which demands urgent attention of all concerned stake holders ranging from individuals to corporate entities (Friedman, 2007). This is more crucial for corporations particularly multinational corporations (MNCs) to understand and thereby, work to come up with ways to address this issue. This over utilization is not only the causing resource depletion but also resulting in frequent occurrence of natural disasters such as tsunamis, floods, acid rains, hurricanes and so on. Henceforth, individuals and corporations are required to act responsibly for which applying 'Greener' is the only solution (Hyndman \& Hyndman, 2016). Within every organization, it is the responsibility of every individual starting from top management to each staff member to work on encouraging activities done in a way that require minimal usage of natural resources and application of activities that facilitate greener activities (Opatha \& Arulrajah, 2014).

\subsection{Individual Green Values}

Individuals as employees have a major role to play when it comes to achieving any organizational aspirations. Similarly, green practices, management and their implementation can only be effectively seen in action when the individual green values are developed. In other words, individual green values are required to be enhanced and enriched which is the major prospect that can help organizations facilitate their aspirations in this line (Edwards \& Shipp, 2007). However, the question comes in place as to how these values can be developed and/or enhanced in the individuals.

Research suggests that implementation of practices and policies at the workplace have a major impact on how employees would behave. It sets them in to a 'pro-environment' behavior at work (Bissing-Olson et al., 2013). Likewise, research suggests that individual green values can be responsively influenced from the green practices (Dumont et al., 2017). This suggests that with green practices in hand, organizations can help enhance individual green values. Moreover, if the organizations practice green HR principles as well such as green recruitment activities, green training initiatives, green benefits and compensation and green management practices, this will showcase a clear ambition and focus of the business towards greener entities (Shen et al., 2018). 


\subsection{Green HRM}

The term with its complete essence refers to the set of activities pertaining to the maintenance and development of human capital in an organization in a way that makes the organization green. In simple, it refers to redesigning and revitalizing HR concerned activities in ways that would results in eliminating unhealthy activities and promoting nature friendly prospects (Guerci et al., 2016). The core ideology behind green HRM is to transform not only the activities but also the workforce into green workforce as well. This as a whole refers to ways laws, policies and practices are designed to make employees behave with greener approach that benefits the nature, conservation of natural resources and societal preferences (Uddin \& Islam, 2015).

Research has proved that green practices have significant impact on organizational performance as well. For instance, O'Donohue and Torugsa (2016) outlined that green HRM activities can improve financial performance in parallel, Renwick et al. (2013) critically appraised the topic and suggested that green HRM does not relate to benefiting the nature and natural resources only. It supports and facilitates several organizational objectives including citizenship, performance, customer service and business efficiency. The role of green HRM is also to work with focus, care and concern for the environmental aspects whereby, all individuals play their parts in the company as a non-polluter and conservationist (HaddockMillar et al., 2016). This, hence, leads us to understand that green HRM can cater to all wider variety of business activities and interests through which people and organizational places could be facilitated with greener recruitment, selection, training, compensation, appraisal and business operations practices.

\subsection{Importance of Green HRM}

Comprehending with the concept of green HRM and why it is crucial for businesses these days can be understood from several dimensions. It is important to understand that Green HRM has a sematic impact on the entire organization and business working since it takes towards devising strategies, policies and practices for the workforce and guide the business operations for responsive working. Hence, the green HRM will enable businesses to work on initiating practices that would help in achieving business goals whilst being responsive to the nature to avoid pollution; minimize carbon footprint; avoid over-usage of natural resources, applying healthier and environment friendly practices related to human capital and utilization of all needed entities and supplies in a way that indicates greener initiation (Renwick et al., 2008). According to Lähtinen et al. (2009) organizations use a wide range of resources, materials and other related stuff to operate which through the strategic engagement of HRM authorities could be revised to ensure they provide utmost services with minimal usage of the societal elements. Green HRM and any practices pertaining to this aspect could be of great help to ensure sustainability of the environment (Dao et al., 2011). Literature has explained that some of such type of activities also refer to corporate citizenship behavior which is essential for businesses these days to showcase ethical behavior. This has a longterm impact not only on the business but also on the society at large. Government bodies play a major role to play in this regard as well to ensure there are national laws and policies in place and there are enforcement agencies actively playing their part to ensure effective application. This is why, Rothenberg (2003) asserted that the protection and nurturing of environmental management require significant involvement of human resource management provided they have a greener focus.

In the view of Milliman and Clair (2017), green HRM is important to promote environmentally friendly operations, services, policies, practices and procedures. Therefore, it can be asserted that green HRM can help facilitate the development and implementation of responsive activities related to employee development that mark less harm to the nature, natural resources and the environment at large. This assertion can be further strengthened with the explanation of Jabbour (2011) who suggested that green practices can make a major role towards the societal wellbeing whereby, HRM practices can play a pivotal role too in this regard. 


\subsection{Green Management and Its Moderation}

Green Management denotes to a managerial umbrella under which initiates are taken to enrich and improve the basis of environmental management. This may cater and involve entities such as establishment of environmentally responsible business practices, development of environmental management system within an organization, allocation of human capital for the design and development of environmentally responsible business practices etcetera (Ahmed et al., 2018; Alfred \& Adam, 2009; Haseeb et al., 2019). The idea of green management not only refers merely to development of environment friendly practices but also it refers to the implementation and execution of those. This in a way caters to developing and designing work prospects that have a better understanding and acceptance of greener practices across the board (Ahmed et al., 2016a,b).

Several scholarly papers and organizational studies have underlined the critical role and importance of green management. According to Barin Cruz and Avila Pedrozo (2009) green management practices can enable managers to protect the environment, enforce the wiser usage of resources minimize the wastage particularly the ones that are directly or indirectly coming from natural entities. Likewise, Jabbour and de Sousa Jabbout (2016) highlight that green management has a noteworthy role when it comes to reduction of greenhouse gases, elimination of carbon footprints and so on.

One important question has been discussed is that why businesses are now being pushed for green management and the best answer to this is what Crane et al. (2019) underlined is the globalization and growing awareness result due to this (Sangakala et al., 2016). People across the globe are becoming more and more aware of the promises and the need for green management to safeguard our economy, society and environment for long term sustainability. Hence, they lead towards establishing effective approaches prospects for environment such as saving natural resources like water and air.

Accordingly, social prospects like sustainability of business, wellbeing of customers, employees and other stake holders whilst maintaining profits ethically which is an economic prospect. In a nutshell, green management supports ecological entities of the environment in which the business operates with visible foundations to showcase its practices (Hu, 2015; Ahmed et al., 2017). Critical appraisal of the literature discussed above suggested that green management plays a major impact on enhancing business outcomes and workforce behaviors. Therein, some evidence pinpointing that management emphasis and focus on the green prospects that further all other similar prospects (Mustapha et al., 2017). Particularly when it comes to individual green values, it could be very well comprehended as when the employees will witness management initiatives towards green practices, they will be encouraged to maximize on the available green prospects such as Green HRM practices and other to further their individual interest respectively thus boosting their green values (Ahmed et al., 2016b; Florida \& Davison, 2001).

\section{Proposed Hypotheses}

Keeping in view of the critical appraisal of the literature, pertaining to green HRM and individual green values, the study believes that the Green HRM practices will be able to help employees understand the importance vitality and focus towards greener prospect at work thus enhancing their individual green values respectively. Henceforth, the following hypothesis was tested:

$\mathrm{H}_{1}$ : Green HRM will positively influence individual Green Values.

Accordingly, in light of the scholarly debate and arguments, the authors reached to the understanding that management focus, emphasis and implementation towards green practices would help employees realize the acute role and significance of green prospects for the business and its management at large. Therefore, the following hypothesis was tested: 
$\mathrm{H}_{2}$ : Green Management will positively influence individual Green values.

In parallel, the paper appraised evidence and scholarly assertions underlining the potential possibility of green management buffering the relationship between green HRM and individual green values, the authors reached the understanding that management focus, attention and implementation of green management practices would help individuals to further their individual green values through green HRM. Thus, the following hypothesis was tested:

$\mathrm{H}_{3}$ : Green Management will moderate the relationship between green HRM and individual green values.

\section{Methodology}

\subsection{Sampling}

A large private distribution business in Bahrain was chosen for the present study. The company was chosen based on its recent initiatives towards green practices across the major work prospects. Therein, non-managerial employees were selected including officers, staff members, assistant and clerical employees. The reason behind choosing non-managerial employees was to have an objective view of what and how general staff members view Green HRM and Green Management practices and their influence on individual green values. Based on the personnel report, the company had 173 non managerial employees and they were all considered as sample for the present study. According to Krejcie and Morgan (1970) table, minimum sample for this number of employees is 123 . Thus, to achieve this target, 150 employees were randomly targeted based on their availability during the three different work shifts. Out of the total 150, 19 questionnaires were discarded due to their incompleteness. Conclusively, 131 questionnaires were taken forward for the analysis and interpretation.

\subsection{Instrument}

8-item scale by Dumont et al. (2017) was adapted to examine green HRM. Accordingly, 5-item scale for individual green values was also adapted from the same study. Lastly, Green et al. (2012) 6-item scale was adapted to test the direct and moderating effect of green management.

\subsection{Analysis}

Structural equation modelling using Smart PLS 2.0 M3 was used to test the hypothesized relationships. As per the recommendations of Henseler et al. (2009) the present study applied two stage analysis approach. Therein, the first stage is known as measurement model assessment in which psychometric properties of the conceptualized model are examined. The second stage is the examination of the structural model which includes the test of the hypothesized relationships.

\subsection{Measurement Model Assessment}

As discussed, psychometric properties of the model were examined in the first stage whereby, individual item reliability, composite reliability and internal consistency were examined. Based on the recommendations of Fornell and Larcker (1981) individual item loadings were assessed at the first place which are recommended to be equal or above 0.50 . Therein, one item from green management was deleted due to loading lower than 0.50 . Accordingly, AVE scores were also examined to affirm convergent validity following to recommendation of Chin (1998) which suggests it to be above also greater than 0.50 . Therein, all the AVE scores for the three constructs ranged between 0.599 and 0.782 . Furthermore, composite reliability was also examined which as per Bagozzi and Yi (1988) recommended to be above 0.70. The CR scores ranged from 0.88 to 0.947 thus confirming internal consistency reliability. Fig. 1 and Table 1 offer further details in this regard. 
Table 1

Individual Loadings, AVE and Composite Reliability

\begin{tabular}{|c|c|c|c|c|}
\hline Construct & Loadings & AVE & Composite Reliability & $\mathbf{R}^{2}$ \\
\hline Green HRM & & 0.601 & 0.923 & \\
\hline GHR1 & 0.675 & & & \\
\hline GHR2 & 0.692 & & & \\
\hline GHR3 & 0.782 & & & \\
\hline GHR4 & 0.791 & & & \\
\hline GHR5 & 0.812 & & & \\
\hline GHR6 & 0.830 & & & \\
\hline GHR7 & 0.807 & & & \\
\hline GHR8 & 0.800 & & & \\
\hline Green Management & & 0.599 & 0.881 & \\
\hline GRM1 & 0.779 & & & \\
\hline GRM2 & 0.731 & & & \\
\hline GRM3 & 0.792 & & & \\
\hline GRM4 & 0.806 & & & \\
\hline GRM5 & 0.759 & & & \\
\hline Individual Green Values & & 0.782 & 0.947 & 0.556 \\
\hline IGV1 & 0.820 & & & \\
\hline $\mathrm{IGV} 2$ & 0.898 & & & \\
\hline IGV3 & 0.902 & & & \\
\hline IGV4 & 0.882 & & & \\
\hline IGV5 & 0.851 & & & \\
\hline
\end{tabular}

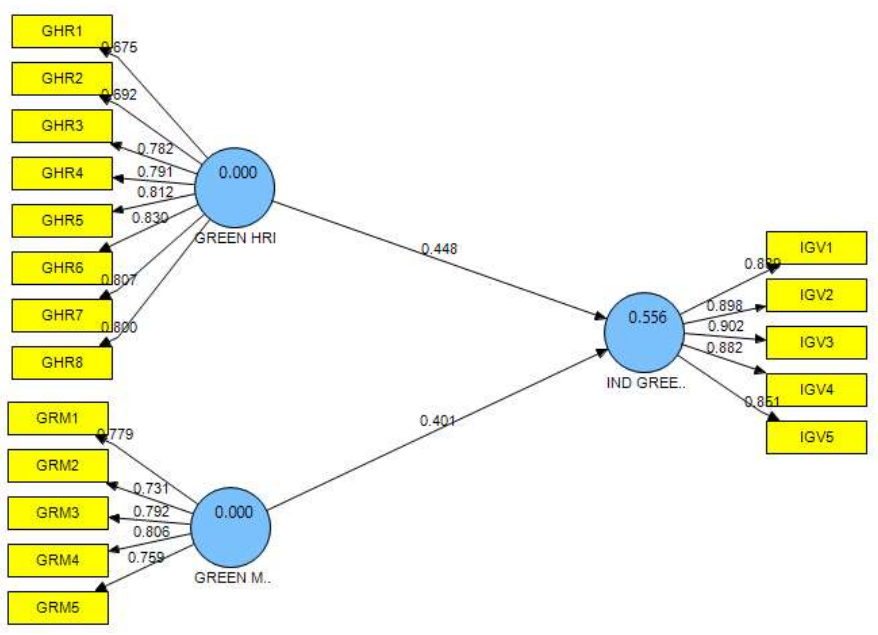

Fig. 1. Measurement Model Assessment

The study also examined the discriminant validity of the conceptualized model and tested constructs through following the recommendations of Fornell and Larcker (1981). For this, the square root of the AVE scores of each construct is taken and compared against the predicting values in a cross loading table. As per the scholars, these square root values should be higher than the values they are cross compared with. Table 2 provides details on this matter suggesting that all the constructs achieve values significantly higher than the compared ones.

\section{Table 2}

Discriminant Validity.

\begin{tabular}{cccc}
\hline & GREEN HRM & GREEN MGMT & IND GREEN VAL \\
\hline GREEN HRM & 0.775 & & \\
GREEN MGMT & 0.545 & 0.774 & 0.884 \\
IND GREEN VAL & 0.666 & 0.644 & \\
\hline
\end{tabular}

Values in BOLD highlight the square root of AVE scores for each of the construct 


\subsection{Structural Model Assessment}

Following the effective achievement of measurement model assessment results, the present study proceeded with the structural model examination in which, the significance of the path coefficients of the hypothesized relationships were tested. The bootstrapping approach results for 131 samples reported a significant positive relationship between green HRM and individual green values hence supporting hypothesis $1(\beta=0.522 ; t=12.829)$. Accordingly, the present study also resulted significant positive relationship between green management and individual green value enhancement $(\beta=0.361 ; t=8.938)$ hence confirming acceptance of hypothesis 2 . Lastly, the study also found significant moderation of green management on the relationship between green HRM and individual green values $(\beta=0.344 ; \mathrm{t}=11.192)$ thus, hypothesis 3 was also accepted. Table 3 and figure 2 provides more details in this regard.

Table 3

Structural Model Results

\begin{tabular}{lcccc}
\hline \multicolumn{1}{c}{ Relationship } & $\beta$ & Std Error & t-Value & Decision \\
\hline GREEN HRM $\rightarrow$ IND GREEN VALUES & 0.5222 & 0.0407 & 12.829 & Supported \\
GREEN MGMT $\rightarrow$ IND GREEN VALUES & 0.3614 & 0.0404 & 8.938 & Supported \\
GREEN HRM * GREEN MGMT $\rightarrow$ IND GREEN VALUES & 0.3441 & 0.0307 & 11.192 & Supported \\
\hline
\end{tabular}

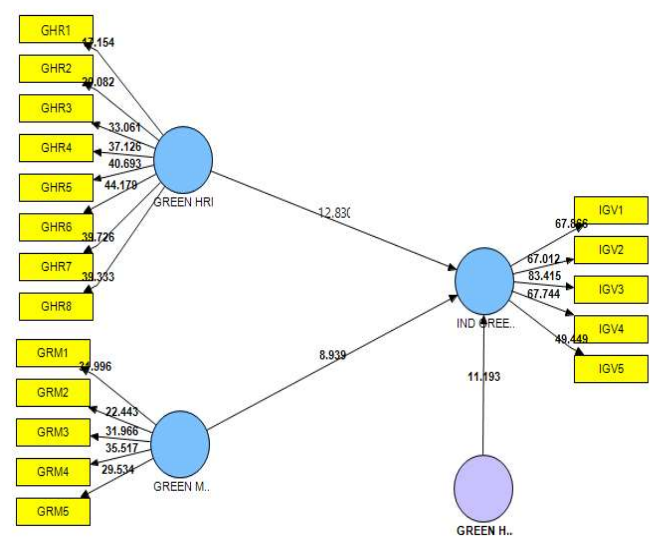

\section{Discussion}

Fig. 2. Direct and Moderation Results

The present study attempted to test some of the important topics in the business arena these days which is the idea of 'Green'. The study responsively tested the role and impact of green HRM and green management on individual green values. The study found significant relationship between green HRM and individual green values which suggests that when organizations have personnel activities with a clear flavor of green prospects, it would help employees understand and realize the vitality accordingly and develop one's individual green values respectively. The finding is in line with the scholarly assertions of Lähtinen et al. (2009) suggesting that organizations need to work on developing greener HRM practices in order to enhance green values amongst their employees. Similarly, the present study also found a significant positive relationship between green management and enhancement of individual green values hence suggesting that organizations need to look into developing and implementing green management practices so to encourage and make their employees responsively green too. This is in support to the arguments of Barin Cruz and Avila Pedrozo (2009) that businesses need to work on developing strong green management principles, policies and practices to ensure their employees follow their foot-steps. Importantly, the study also found significant moderation of green management on the relationship between green HRM and individual green values. This suggests that employees were in a better position to capitalize upon green HR prospects to further their individual green values when they perceived the presence of green management as well. In other words, green management can buffer the vitality of Green HRM to help employees enhance their green values. The study has reported significant findings 
that could be of great support and importance for businesses to enhance their green outlook across the board.

\section{Implications}

The findings of the present study have several noteworthy implications for businesses and practitioners in particular. Important to note that individual green values is the core for all businesses aspiring for green practices and management in their organizations. Therein, at first, the current study based on the significant relationship between Green HRM and individual green value implies that organizations aiming and aspiring for inducing green initiation and activities in the company may take a great start from this point. Through revitalizing HRM related activities with a green flavor could help them highlight and motivate employees towards realizing company focus and attribution towards this thus enhancing their individual values accordingly. This also implies that when organization performs major personnel related activities in a greener way, it will develop a sense of understanding and concern for the same in the employees as well. Hence, organizations need to work on refining the HRM practices to ensure the employees develop the similar values.

Accordingly, following the green management and individual green value relationship significance, the present study implies management to ensure that they are practicing in green prospects by themselves. This implies that organizations should work on developing policies, practices and procedures that would yield support and provide a blueprint for business and its human capital to work accordingly. Moreover, based on the significant moderation results of green management, companies are implied that with the help of green management practices in place, employees will be able to responsively capitalize upon the Green HR practices to further their individual green values. In way a lead to a conclusive assertion that all the green initiations and practices can responsively go hand in hand to help employees enhance their green values. Accordingly, availability of green management will be able to help them to make the most of green HRM practices to further their individual green values.

\section{Limitations and Scope for Future Studies}

The present study was conducted with a cross section approach through using a case study approach which limits the causal inferences of the study results. Thus, future studies may consider looking into longitudinal studies. Accordingly, the study was limited to one sector hence, future scholars may consider looking into other work sectors. Similarly, the current study explained 0.56 in other words, $56 \%$ of variance towards green values thus, future studies may also consider looking into other factors and variables that could help to understand how individual green values can be further enhanced. Future scholars may also consider looking at other factors and variables that could be of potential in explaining intervening effect or buffering effect on the same hypothesized relationships.

\section{Conclusion}

The present study responsively has concluded with notable results confirming the noteworthy role and impact of green HRM and green management towards boosting individual green values. The study has helped organizational scholars understand a much greater role and contribution towards explaining how green prospects are vital and could be enhanced for sustainable business in particular and environment at large.

\section{References}

Ahmed, U., Khalid, N., Ammar, A., \& Shah, M. H. (2017). Assessing moderation of employee engagement on the relationship between work discretion, job clarity and business performance in the banking sector of Pakistan. Asian Economic and Financial Review, 7(12), 1197. 
Ahmed, U., Majid, A. H. A., \& Zin, L. M. (2016a). Construct validation of 17-item Utrecht University work engagement scale amongst the white collar employees of Malaysian Universities. International Journal of Academic Research in Business and Social Sciences, 6(5), 306-312.

Ahmed, U., Majid, A. H. A., \& Zin, M. M. (2016b). Moderation of meaningful work on the relationship of supervisor support and coworker support with work engagement. The East Asian Journal of Business Management (EAJBM), 6(3), 15-20.

Ahmed, U., Shah, S. A., Qureshi, M. A., Shah, M. H., \& Khuwaja, F. M. (2018). Nurturing innovation performance through corporate entrepreneurship: The moderation of employee engagement. Studies in Business and Economics, 13(2), 20-30.

Alfred, A. M., \& Adam, R. F. (2009). Green management matters regardless. Academy of Management Perspectives, 23(3), 17-26.

Alshuwaikhat, H. M., \& Abubakar, I. (2008). An integrated approach to achieving campus sustainability: assessment of the current campus environmental management practices. Journal of cleaner production, 16(16), 1777-1785.

Bagozzi, R. P., \& Yi, Y. (1988). On the evaluation of structural equation models. Journal of the Academy of Marketing Science, 16(1), 74-94.

Barin Cruz, L., \& Avila Pedrozo, E. (2009). Corporate social responsibility and green management: relation between headquarters and subsidiary in multinational corporations. Management Decision, 47(7), 1174-1199.

Bissing-Olson, M. J., Iyer, A., Fielding, K. S., \& Zacher, H. (2013). Relationships between daily affect and pro-environmental behavior at work: The moderating role of pro-environmental attitude. Journal of Organizational Behavior, 34(2), 156-175.

Chin, W. W. (1998). The partial least squares approach to structural equation modeling. Modern methods for business research, 295(2), 295-336.

Crane, A., Matten, D., Glozer, S., \& Spence, L. (2019). Business ethics: Managing corporate citizenship and sustainability in the age of globalization. Oxford University Press.

Dao, V., Langella, I., \& Carbo, J. (2011). From green to sustainability: Information Technology and an integrated sustainability framework. The Journal of Strategic Information Systems, 20(1), 63-79.

Dumont, J., Shen, J., \& Deng, X. (2017). Effects of green HRM practices on employee workplace green behavior: The role of psychological green climate and employee green values. Human Resource Management, 56(4), 613-627.

Edwards, I. R., \& Shipp, A. I. (2007). The relationship between person-environment fit and outcomes: An integrative. Perspectives on organizational fit, 209.

Florida, R., \& Davison, D. (2001). Gaining from green management: environmental management systems inside and outside the factory. California management review, 43(3), 64-84.

Fornell, C., \& Larcker, D. F. (1981). Evaluating structural equation models with unobservable variables and measurement error. Journal of marketing research, 18(1), 39-50.

Friedman, T. L. (2007). The power of green. The New York Times, 15.

Green Jr, K. W., Zelbst, P. J., Meacham, J., \& Bhadauria, V. S. (2012). Green supply chain management practices: impact on performance. Supply Chain Management: An International Journal, 17(3), 290-305.

Guerci, M., Longoni, A., \& Luzzini, D. (2016). Translating stakeholder pressures into environmental performance-the mediating role of green HRM practices. The International Journal of Human Resource Management, 27(2), 262-289.

Haddock-Millar, J., Sanyal, C., \& Müller-Camen, M. (2016). Green human resource management: a comparative qualitative case study of a United States multinational corporation. The International Journal of Human Resource Management, 27(2), 192-211.

Haden, S.S., Oyler, P.H., \& Humphreys, J.H. (2009). Historical, practical and theoretical perspectives on green management: an exploratory analysis. Management Decision, 47(7), 1041-55.

Haseeb, M., Hussain, H. I., Ślusarczyk, B., \& Jermsittiparsert, K. (2019). Industry 4.0: A solution towards technology challenges of sustainable business performance. Social Sciences, 8(5), 154. 
Henseler, J., Ringle, C. M., \& Sinkovics, R. R. (2009). The use of partial least squares path modeling in international marketing. In New challenges to international marketing (pp. 277-319). Emerald Group Publishing Limited.

Hu, A. (2017). China: Innovative green development. Springer Singapore.

Hyndman, D., \& Hyndman, D. (2016). Natural hazards and disasters. Cengage Learning.

Jabbour, C. (2011). How green are HRM practices, organizational culture, learning and teamwork? A Brazilian study. Industrial and Commercial Training, 43(2), 98-105.

Jabbour, C. J. C., \& de Sousa Jabbour, A. B. L. (2016). Green human resource management and green supply chain management: Linking two emerging agendas. Journal of Cleaner Production, 112, 1824-1833.

Jackson, S. E., \& Seo, J. (2010). The greening of strategic HRM scholarship. Organization Management Journal, 7(4), 278-290.

Krejcie, R. V., \& Morgan, D. W. (1970). Determining sample size for research activities. Educational and psychological measurement, 30(3), 607-610.

Kumari, P. (2012). Green HRM-Issues and challenges. Global Research Analysis, 1(5), 80-83.

Lähtinen, K., Toppinen, A., Leskinen, P., \& Haara, A. (2009). Resource usage decisions and business success: a case study of Finnish large-and medium-sized sawmills. Journal of Forest Products Business Research, 6(3), 1-18.

Milliman, J., \& Clair, J. (2017). Best environmental HRM practices in the US. In Greening People (pp. 49-73). Routledge.

Mustapha, M. A., Manan, Z. A., \& Alwi, S. R. W. (2017). Sustainable Green Management System (SGMS)-An integrated approach towards organisational sustainability. Journal of Cleaner Production, 146, 158-172.

O'Donohue, W., \& Torugsa, N. (2016). The moderating effect of 'green' HRM on the association between proactive environmental management and financial performance in small firms. The International Journal of Human Resource Management, 27(2), 239-261.

Opatha, H. H. P., \& Arulrajah, A. A. (2014). Green human resource management: Simplified general reflections. International Business Research, 7(8), 101.

Renwick, D. W., Redman, T., \& Maguire, S. (2013). Green human resource management: A review and research agenda. International Journal of Management Reviews, 15(1), 1-14.

Renwick, D., Redman, T., \& Maguire, S. (2008). Green HRM: A review, process model, and research agenda. University of Sheffield Management School Discussion Paper, 1, 1-46.

Rothenberg, S. (2003). Knowledge content and worker participation in environmental management at NUMMI. Journal of management studies, 40(7), 1783-1802.

Sangakala, M., Ahmed, U., \& Pahi, M. H. (2016). Empirical investigating on the role of supervisor support, job clarity, employee training and performance appraisal in addressing job satisfaction of nurses. International Business Management, 10(23), 5481-5486.

Shen, J., Dumont, J., \& Deng, X. (2018). Employees' perceptions of green HRM and non-green employee work outcomes: The social identity and stakeholder perspectives. Group \& Organization Management, 43(4), 594-622.

The Oxford Thesaurus of English. (2000). Oxford: Oxford University Press.

Uddin, M. M., \& Islam, R. (2015). Green HRM: Goal attainment through environmental sustainability. Journal of Nepalese Business Studies, 9(1), 14-19.

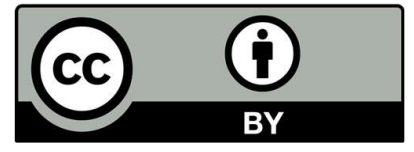

(C) 2019 by the authors; licensee Growing Science, Canada. This is an open access article distributed under the terms and conditions of the Creative Commons Attribution (CCBY) license (http://creativecommons.org/licenses/by/4.0/). 